\title{
Democracy and (European) Private Law: A Functional Approach
}

Jan M. Smits*

\section{Introduction}

The development towards a Common Frame of Reference for European private law ${ }^{1}$ not only raises questions about what should be the contents of private law rules for the European Union, ${ }^{2}$ but it also challenges our traditional understanding of how rules of private law should come into being. In the European member states, private law is traditionally 'made' in close cooperation between the national legislatures and the courts: it is the result of an intricate decision-making process at the national level, in which legal academia is often also involved. ${ }^{3}$ This is, to varying degrees, true for both civil law and common law jurisdictions.

The drafting of the Common Frame of Reference prompts the question to what extent its rules should meet similar requirements as to legitimacy as the national rules in the member states. The prevailing view seems to be that the rules of the Draft CFR (DCFR) do not meet the requirements of democratic legitimacy necessary in the field of private law. Given that the DCFR was drafted by legal scholars, united in the Study Group on a European Civil Code and in the Research Group on the Existing EC Private Law, the DCFR would, in this respect, be a typical example of Professorenrecht. This is also acknowledged by the drafters, who presented their text as an "academic CFR", a scholarly product that is not politically

\footnotetext{
* Jan Smits is professor of European Private Law and Comparative Law at Tilburg University (Tilburg Institute of Comparative and Transnational Law) and visiting professor of Comparative Legal Studies at the University of Helsinki (Center of Excellence on European Law and Polity). This paper expands on ideas raised in J.M. SMITS, "European Private Law and Democracy: A Misunderstood Relationship", in M. FAURE and F. STEPHEN, Essays in the Law and Economics of Regulation in Honour of Anthony Ogus, Oxford, Intersentia, 2008, pp. 49-59. It benefits from discussion at the conference Globalisation and Private Law, held in Stellenbosch on 18-20 December 2008, and at a seminar in Helsinki on 13 January 2009. Thanks are due to Jennifer Jun for invaluable research assistance.

${ }^{1}$ C. VON BAR et al, Principles, Definitions and Model Rules of European Private Law: Draft Common Frame of Reference, Interim Outline Edition, München, Sellier, 2008.

${ }^{2}$ The Draft CFR was already elaborately discussed from this, and other, perspectives. See, e.g., A. VAQUER, European Private Law Beyond the Common Frame of Reference, Groningen, Europa Law Publishing, 2008, special issue of the European Review of Contract Law , 2008, No 3, pp. 223-454; F. CAFAGGI and H. MICKLITZ, After the Common Frame of Reference: What Future for European Private Law?, Cheltenham, Edward Elgar, 2009.
} 
legitimised and that, at best, could form the basis for a "political CFR" to be drafted by the European Commission. But it is difficult to deny that, in drafting the DCFR, many relevant choices were made. In a recent book, Bastiaan van Zelst therefore sketches the following objections against this working method:

\footnotetext{
"This seems worrying from two different angles. First of all, the scholars that are involved in the drafting of the DCFR lack democratic legitimacy. The group represents neither all of the populations of the member states, nor their political convictions. Secondly, it is questionable whether professors should be vested with the translation of social-political reality into legislation. In a democratic society, this would seem to principally be the task of the (democratically legitimised) legislature [... $]^{\prime 4}$.
}

Other authors, most of them united in another group, namely the Study Group on Social Justice in European Private Law, ${ }^{5}$ also hold the view that the Europeanisation of private law should take place in a much more democratic way than is the case at present. This would not only be true for the DCFR, but for any attempt to create a European private law. These authors are clearly influenced by the Critical Legal Studies view that all law, including private law, is politics. ${ }^{6}$ In other words, if private law shapes the distribution of wealth in a modern society, creating a future European private law would primarily be a political process. Therefore, the rules of contract law that account for the right balance between the free market and social justice should be determined in a democratic way. Only consulting 'stakeholders' and legal practice in drafting new European rules -as the European Commission proposes- is then not enough; instead, the European Parliament and national legislators, including national parliaments, must be involved. ${ }^{7}$ From a different theoretical perspective, Alain Verbeke recently also argued that the Europeanisation process of private law should be "re-

3 Cf R.C. VAN CAENEGEM, Judges, Legislators and Professors: Chapters in European Legal History, Cambridge, Cambridge University Press, 1987.

${ }^{4}$ B. VAN ZELST, The Politics of European Sales Law, The Hague, Kluwer Law International, 2008, pp. 244245.

5 STUDY GROUP ON SOCIAL JUSTICE IN EUROPEAN PRIVATE LAW, "Social Justice in European Contract Law: A Manifesto", European Law Journal, 2004, pp. 653-674. See also: M.W. HESSELINK, "The Politics of a European Civil Code", European Law Journal, 2004, pp. 675-697; M.W. HESSELINK, "The Ideal of Codification and the Dynamics of Europeanization: The Dutch Experience", in S. VOGENAUER and S. WEATHERILL, The Harmonisation of European Contract Law, Oxford, Oxford University Press, 2006, pp. 39-70; U. MATTEI, "Hard Code Now! A Critique and a Plea for Responsibility in the European Debate over Codification", in U. MATTEI, The European Codification Process: Cut and Paste, The Hague, Kluwer Law International, 2003, pp. 107-128.

${ }^{6}$ Cf D. KENNEDY, "Form and Substance in Private Law Adjudication", Harvard Law Review, 1976), pp. 16851778; D. KENNEDY, “The Political Stakes in 'Merely Technical' Issues of Contract Law”, European Review of Private Law, 2002, pp. 7-28. 
politicised". ${ }^{8}$ This is an important view: if these authors are correct about their "democracy thesis', it means that European private law needs to be 'made' in a very different way than it is now.

In this contribution, I argue that this view -the 'democracy thesis'- is mistaken. The present Europeanisation and globalisation processes should radically change our view of how rules, either existing or new ones, in the area of private law are legitimised. My aim is not to reiterate the entire debate about the legitimacy of new modes of governance, ${ }^{9}$ but to focus directly on rules that seek to regulate the conduct of private parties. It is thus the core of private law, and specifically the law of contract, with which I am concerned. In this area, I argue that there are different (and better) ways of legitimising private law outside of national parliaments.

This contribution is structured as follows. Section II begins with a more general overview of new types of rule-making that, although they evade the democratic decisionmaking process, are important in regulating the behaviour of individuals and states. This raises the question of to what extent the emergence of these new types of rules pose a problem for the legitimacy of private law. I argue that the problem arises only if we perceive legitimacy in a very restrictive way, limiting it to democratic decision-making by national parliaments. Section III therefore proposes an alternative approach, a functional one, in which the concept of democracy is deconstructed into various building blocks. This more general theoretical framework should then allow us to assess the Draft CFR in more detail in section IV. Section V sums up the main argument.

\section{Law without a state: A problem of democracy?}

The drafting of legal rules by academics for the future application of these rules by private parties or states -as in the case of the Draft CFR- is only one example of so-called

\footnotetext{
${ }^{7} C f$ STUDY GROUP ON SOCIAL JUSTICE, "Manifesto", o.c., p. 669.

${ }^{8}$ A. VERBEKE, "Negotiating (in the Shadow of a) European Private Law", Maastricht Journal of European and Comparative Law, 2008, pp. 395-413, at note 15.

${ }^{9} \mathrm{C} f$ e.g. D. CURTIN and R.A. WESSEL, Good Governance and the European Union, Antwerp, Intersentia, 2005; B. EBERLEIN and D. KERVER, "New Governance in the European Union", Journal of Common Market Studies, 2004, at p. 121.
} 
"private global norm-production". ${ }^{10}$ Over the last decades, an increasing number of rules and policies were developed beyond the nation-state. ${ }^{11}$ Apart from the European Union, which has its own procedures for legitimising the rules it produces, important policy decisions are made by organisations such as the WTO, IMF and World Bank. In the area of private law, the ageold example of the lex mercatoria" is now supposedly supplemented by the "lex laboris internationalis"13 and the "lex sportiva internationalis". 14 In addition to this, types of voluntary law, ${ }^{15}$ such as norms adopted by corporate networks -the most important example being codes of conduct for corporate social or environmental responsibility-, rules of standardisation organisations for technical standards, such as the "codex alimentarius", and other types of self-regulation ${ }^{16}$ are also supposed to influence the conduct of private parties.

Most of these authoritative rules, norms and policies from "sites of governance beyond the nation-state" ${ }^{, 17}$ would not count as binding law in a traditional conception of legal rules: they do not meet the formal criterion of being enacted by the relevant authorities. But they often do set the norms for specific groups of people and are important in predicting their behaviour. One can argue that, as the legitimacy of law was found in the laws of nature in the seventeenth and eighteenth centuries and in democratic political legislation in the nineteenth and twentieth centuries, it is now time to find again a new source of legitimacy for legal rules. ${ }^{18}$ It is clear that such a new source of legitimacy cannot be found in the authority of the state. Not only is the authority of the norms that were just described not dependent on the

\footnotetext{
10 See, for this term, G. TEUBNER, "Breaking Frames: The Global Interplay of Legal and Social Systems", American Journal of Comparative Law, 1997, pp. 149-169, at p. 157.

${ }^{11}$ See, for an elaboration of the idea of private law beyond the nation-state, R. MICHAELS and N. JANSEN, "Private Law Beyond the State? Europeanization, Globalization, Privatization", American Journal of Comparative Law, 2006, pp. 843-890; N. JANSEN and R. MICHAELS, "Private Law and the State", Rabels Zeitschrift, 2007, pp. 345-397; and the special issue of the American Journal of Comparative Law, 2008, pp. 527-844.

${ }^{12}$ Cf recently V. PIERGIOVANNI, From Lex Mercatoria to Commercial Law, Berlin, Duncker \& Humblot, 2005.

${ }^{13} C f$ the contributions in J.D.R. CRAIG and S.M. LYNK, Globalization and the Future of Labour Law, Cambridge, Cambridge University Press, 2006.

${ }^{14}$ See F. LATTY, La "Lex Sportiva”: Recherche sur le Droit Transnational, Leiden, Martinus Nijhoff, 2007; K. FOSTER, "Is There a Global Sports Law?”, Entertainment and Sports Law Journal, 2003, pp. 1-18.

${ }^{15}$ See, for this term, A.-M. SLAUGHTER, "International Law in a World of Liberal States", European Journal of International Law, 1995, pp. 503-538, at p. 518.

16 See F. CAFAGGI, Reframing Self-Regulation in European Private Law, The Hague, Kluwer Law International, 2006; D. SCHIEK, "Private Rule-Making and European Governance: Issues of Legitimacy", European Law Review, 2007, pp. 443-466.

${ }^{17}$ G. DE BURCA, "Developing Democracy Beyond the State", Columbia Journal of Transnational Law, 2008, pp. 101-158, at p. 104

${ }^{18}$ C $f$ G. TEUBNER, "Breaking Frames", o.c., p. 157.
} 
state, their authority is also no longer exercised within clearly defined territorial entities; instead, the relevant rules are often chosen and applied across existing borders. ${ }^{19}$ Issues that were previously within the domain of democratic decision-making at the national level have thus shifted to the international level.

If we accept that this type of lawmaking beyond the national state is becoming more and more important, what does this mean for the democratic legitimacy of the rules created in this process? In a recent article, Grainne De Burca distinguishes several approaches in understanding the relationship between democracy and trans-national law. ${ }^{20}$ If legitimacy is a legal concept that cannot be replaced by efficiency or expertise -meaning: public power exercised outside of the authority of the state should not escape the expectation of democratic legitimation-, ${ }^{21}$ the best approach is one that tries to find alternatives for democracy. The democratic ideal should then be pursued in forms other than through the national parliament. With the multiplication of legal sources, the need for such a rethinking of democracy is very clear. $^{22}$ The opposing view -now that there is no trans-national demos and electorate, democracy at another level than the national one is impossible- ${ }^{23}$ cannot be accepted.

The important insight to be derived from this is that (private) law does not necessarily have to find its legitimacy in the decisions of national parliaments. ${ }^{24}$ Such a view would regard legitimacy in a very restrictive way. It is true that, since the eighteenth century, democracy was closely associated with the state, but this need not be the case. The idea of democracy was present long before the nation-state was developed, ${ }^{\mathbf{2 5}}$ and now that we accept law that transcends the boundaries of a territory and a people, we need to again dissociate democracy from the state. The question therefore is how to change our conception of law,

19 J. DELBRÜCK, "Exercising Public Authority Beyond the State: Transnational Democracy and/or Alternative Legitimation Strategies?”, Indiana Journal of Global Legal Studies, 2003, pp. 28-43, at p. 29.

${ }^{20}$ G. DE BURCA, "Developing Democracy", o.c., p. 117.

${ }^{21}$ G. DE BURCA, "Developing Democracy", o.c., p. 113.

22 See also J. WEILER, quoted by DE BURCA, "Developing Democracy", o.c., p. 105: "what is required is [...] a rethinking of the very building blocks of democracy to see how these may or may not be employed in an international system which is neither state nor nation"; reference is sometimes made to the need for a "cosmopolitan democratic theory".

${ }^{23}$ See R. DAHL, “Can International Organizations be Democratic: A Skeptic's View?", in I. SHAPIRO and C. HACKER-CORDON, Democracy's Edges, Cambridge, Cambridge University Press 1999, pp. 19-36; R. DAHL, On Democracy, New Haven \& London, Yale University Press, 1998.

${ }^{24}$ See also, for this debate, MICHAELS and JANSEN, o.c., p. 879; criticised by F. RÖDL, "Private Law Beyond the Democratic Order? On the Legitimatory Problem of Private Law 'Beyond the State", American Journal of Comparative Law, 2008, pp. 743-767, at p. 751. 
very much based on the nation-state experience, so as to meet the different conditions of global governance. ${ }^{\mathbf{2 6}}$ The importance of such a venture is paramount because, as one author puts it, "democracy will be possible beyond the nation-state - or democracy will cease to be possible at all". ${ }^{27}$

In the next section, it is attempted to deconstruct democracy into various building blocks. If we establish the functions that democracy currently fulfils, we can subsequently see whether these functions can be fulfilled in another way than through national parliaments.

\section{Deconstructing democracy}

The approach followed in this section is one in which the concept of democracy is deconstructed into various building blocks. If we are able to define the functions of democracy, it is possible to establish whether these functions can also be fulfilled in another way in the area of European or even global lawmaking. It is clear that finding such substitutes for the democratic legitimacy of law is only possible when we stop thinking in terms of national states or parliaments. Instead, the legitimacy of law should be found in other factors. It is also important to realise that our concern is not with all aspects of democracy or of tasks of national parliaments: as indicated above, this paper only deals with the lawmaking process, in particular, in the area of private law. Having said this, this section first suggests that it is not democracy that is at stake when drafting law, but rather the legitimacy of the rules in question. Second, it is argued that such legitimacy can be found in three different factors.

It should first be acknowledged that it is difficult to use the term democracy for something that is not related to representative government. The present connotation of the word refers so much to parliamentary representation that it can be confusing to use it for mechanisms that are equal to democratic decision-making at other levels than the state. This is one of the reasons why Rubin suggests abandoning the term in political analyses. ${ }^{28}$ It seems better to use the word legitimacy instead, even though this term does not have a fixed

25 J. DUNN, Democracy: A History, New York, Atlantic Press, 2005.

${ }^{26}$ See J. HABERMAS, "The Postnational Constellation and the Future of Democracy”, in J. HABERMAS, The Postnational Constellation: Political Essays, Cambridge, Polity Press, 2001, at p. 58.

${ }^{27}$ A. PELINKA, "Democracy Beyond the State: On the (Im-)Possibilities of Transnational Democracy, Trans: Internet-Zeitschrift für Kulturwissenschaften, No 15/2003. 
meaning. ${ }^{29}$ The legitimacy of a rule could refer to the political procedures used to put that rule into place, but also to its moral contents or acceptance. In my view, it is this latter meaning that is most important: the legitimacy of a rule refers to the perception that it is the most desirable or proper rule to be adopted in the given circumstances. ${ }^{30}$ This makes legitimacy not only dependent on the acceptability of those being affected by the rule, but also on the acceptance by society in general or by the academic forum. ${ }^{31}$ It still leaves open the question of which criteria are decisive for this legitimacy to exist.

Political science tells us that democracy fulfils three different functions: participation, accountability and transparency. ${ }^{32}$ Participation at the national level traditionally consists of the parliamentary representation of everyone in everything. However, when the polity is no longer defined along territorial lines or on the basis of a people -as is the case with the type of rules discussed here- such participation can no longer be based on state institutions. With the trans-nationalisation of law, the more effective forms of participation are likely to be based on groups, creating new political communities along functional lines. ${ }^{33}$

Accountability can be defined as the principle that one is responsible for one's conduct vis-à-vis another person or organisation. Such responsibility usually includes the obligation to inform that person or organisation about one's past or future actions, to justify them and to be held responsible in case of misconduct. ${ }^{\mathbf{3 4}}$ Accountability is thus primarily an "ex post governance mechanism". Traditionally, accountability at the national level is an electoral one:

${ }^{28}$ E.L. RUBIN, “Getting Past Democracy”, University of Pennsylvania Law Review, 2001, pp. 711-792.

${ }^{29}$ Cf J. DELBRUCK, "Exercising Public Authority Beyond the State: Transnational Democracy and/or Alternative Legitimation Strategies”, Indiana Journal of Global Legal Studies, 2003), pp. 29-43.

${ }^{30}$ Cf W.R. SCOTT, Institutions and Organisations, Thousand Oaks, Sage, 2nd ed., 2001: "a generalised perception or assumption that the actions of an entity are desirable, proper, or appropriate within some socially constructed system of norms, values, beliefs, and definitions"; see also J. BLACK, "Constructing and Contesting Legitimacy and Accountability in Polycentric Regulatory Regimes", LSE Legal Studies Working Paper, No 2/2008.

${ }^{31}$ In the definition of SCOTT, Institutions and Organisations, o.c., it is only the perception of the governed that is important.

${ }^{32}$ Cf B. KINGSBURY et al., "The Emergence of Global Administrative Law", Law and Contemporary Problems, 2005, pp. 15-61.

${ }^{33}$ Cf DELBRÜCK, o.c., p. 38: "functional authorities of varying geographical scope run by individuals selected by lot from among those with a material interest in the issue in question"; see also G. DE BURCA, "Developing Democracy", o.c., p. 123; P. HIRST, Associative Democracy: New Forms of Economic and Social Governance, Amherst, University of Massachusetts Press, 1994, p. 19: affairs of society should as much as possible be managed by voluntary and democratically self-governing associations as these have more information than central bureaucracies.

${ }^{34}$ Cf. A. SCHEDLER, "Conceptualizing Accountability", in A. SCHEDLER et al., The Self-Restraining State: Power and Accountability in New Democracies, London, Lynne Rienner Publishers, 1999, pp. 13-28. 
officeholders have to account to those who are entitled to vote for their election. If their performance is insufficient, they will not be re-elected. But this is not a very precise or efficient accountability mechanism: voters do not provide reasons for their votes and can be motivated by many other motives than the standards one wants the officeholders to meet. There are many other types of accountability one can think of, ${ }^{\mathbf{3 5}}$ including fiscal accountability through audit regimes, legal accountability -the accountholder is held liable for a violation of a standard-, hierarchical accountability of employees vis-à-vis their superiors and accountability through the market where the satisfaction of those affected by a policy decides its success.

Transparency, finally, refers to decision-making that is open to the gaze of others does not take place behind closed doors- and that is based on freely available information. As a political norm, however, transparency is rather vague: ${ }^{\mathbf{3 6}}$ it does not make clear who these others are and which information exactly is to be shared with them. Surely, there can be no complete access to government information for everyone and for everything. This makes it important to ask why we actually need transparency. In any democratic theory, the need for openness of government follows from the fact that people can only on the basis of such a theory make a well-informed, rational choice for the government by which to be governed. It also facilitates the public debate crucial in a democratic society and a prerequisite for holding government officials accountable. ${ }^{37}$ Again, this presumes that the transparency requirement is directed towards the public at large. Another approach is to apply the transparency requirement to the group of people most affected by the rules in question. If an important condition for a democracy to be successful is the quality of the deliberation, ${ }^{\mathbf{3 8}}$ it may well be that informed deliberation among specialists leads to greater legitimacy than a general debate among non-specialists.

35 See e.g. the overview, with many references, by G. GARN, "Moving from Bureaucratic to Market Accountability: The Problem of Imperfect Information”, Educational Administration Quarterly, 2001, pp. 571599 , at p. 578.

${ }^{36}$ This is the point made by M. FENSTER, "The Opacity of Transparency", Iowa Law Review, 2006, pp. 885949, at p. 889.

${ }^{37}$ See for all these aspects M. FENSTER, o.c., pp. 895-ff., with reference to James Madison's statement that “a popular government, without popular information, or the means of acquiring it, is but a prologue to a farce or a tragedy; or perhaps both".

38 Deliberative democracy emphasises the importance of a free, rational, debate among citizens, however difficult this may be in practice. The obvious references are to J. RAWLS, Political Liberalism, New York, Columbia University Press, 1993; and J. HABERMAS, Faktizität und Geltung, Frankfurt am Main, Suhrkamp, 1992. 
If we accept these factors as the building blocks of democracy, we have a tool to deal with legitimacy at the trans-national level. One important advantage of this approach is to recognise that these criteria can be met to a greater or to a lesser extent. Often, we do not need the full participation of everyone when dealing with certain issues. Likewise, accountability and transparency are also gradual concepts. ${ }^{39}$ The exact levels of participation, accountability and transparency to meet the legitimacy requirement can thus be made dependent on several factors. ${ }^{40}$ One factor concerns the type of rules: rules of a more technical nature require less 'democratic' legitimacy than rules about issues that are already highly politicised. ${ }^{41}$ Thus, legitimacy can lie in the merits of the decision-makers, such as their ability to give independent expertise. ${ }^{\mathbf{4 2}}$ Another factor concerns the level of harmonisation: minimum harmonisation may need less legitimacy than full harmonisation.

It should be emphasised that this approach also works in the other direction: rules that did pass through the national democratic decision-making process may not meet the requirements of legitimacy as just defined. ${ }^{\mathbf{4 3}}$ The mere fact that a democratic process took place is then not enough to conclude that a rule is sufficiently legitimate. ${ }^{\mathbf{4 4}}$

\section{The legitimacy of the Draft CFR}

With the framework provided in the previous section, we are now able to turn back to the Draft Common Frame of Reference for European private law. Are Van Zelst and others right in claiming that private law should come about in a democratic process with the involvement of national parliaments -the 'democracy thesis'- or is there another way to legitimate the rules of the DCFR? In this section, I provide three arguments as to why (European) private law may not need a democratic basis in the traditional sense because it can

\footnotetext{
39 G. DE BURCA, "Developing Democracy", o.c., p. 107, claims that we need to have "the fullest possible participation and representation of those affected".

40 See A. HÉRITIER, "Elements of democratic legitimation in Europe: an alternative perspective", Journal of European Public Policy, 1999, pp. 269-282, at p. 270.

${ }^{41}$ See e.g. F. FISCHER, Technocracy and the Politics of Expertise, London, Sage, 1990.

42 G. DE BURCA, "Developing Democracy", o.c., p. 122.

43 There is no need to refer to the extensive literature on public choice. Instead of all, see D.A. FARBER and P.P. FRICKEY, Law and Public Choice: A Critical Introduction, Chicago, University of Chicago Press, 1991.

${ }^{44}$ Democratically made deficient legislation can lead to people questioning the usefulness of democracy as a whole. See J. GOLDRING, "Consumer Protection, the Nation-State, Law, Globalization, and Democracy", Journal of Computer-Mediated Communication, 1996, No 2.
} 
meet the three building blocks of democracy in another way. After a discussion about accountability (A) and participation (B), the section on transparency (C) reveals that the nature of private law partly stands in the way of considering it as an area subordinate to policymaking.

\section{A. Accountability: Legitimacy through jurisdictional competition}

In the brief characterisation of accountability provided above, it became clear that the core of the concept consists of a relationship between the relevant actors and a forum and that such a relationship can be established in different ways. If the rule-maker cannot be held responsible in the traditional way -by being voted away-, what could be an alternative? Without claiming this is the only possible way of enhancing the legitimacy of trans-national rules, ${ }^{45}$ I believe that market accountability can be much more important in legitimating law than is usually assumed. This is in particular true in those areas of law that contain many nonmandatory rules, such as the law of contract. If market accountability in, for example, schools means that good schools attract students whereas bad schools are held accountable by students that leave, a similar mechanism can operate in the fields of facilitative law.

This view is, of course, not new. The theory of jurisdictional competition, as developed by Charles Tiebout, ${ }^{\mathbf{4 6}}$ emphasises that when parties have the freedom of choice as to the applicable legal regime -as is the case in large parts of contract law-, they will choose the regime they like best. Such jurisdictional competition is an alternative to allocating local public goods in a political decision-process: the preferences of citizens can be established by allowing the citizens to choose for a particular legal regime, even without these citizens moving physically.

\footnotetext{
${ }^{45}$ One other way of enhancing accountability is to label and rate types of self-regulation or even of contracts: see OMRI BEN-SHAHAR, "The Myth of the 'Opportunity to Read' in Contract Law", University of Chicago Law \& Economics Olin Working Paper, 2008, No 415.

${ }^{46}$ C. TIEBOUT, “A Pure Theory of Local Expenditures”, Journal of Political Economy, 1956, pp. 416-424. See also A. OGUS, "Competition between National Legal Systems: A Contribution of Economic Analysis to Comparative Law”, International and Comparative Law Quarterly, 1999, pp. 405-418.
} 
There are limits to establishing preferences by jurisdictional competition. ${ }^{47}$ The most important limit arises when law is regarded as mandatory by the state. It is difficult to imagine that such mandatory national law would be set by an authority beside the national lawmaker because this concerns the fundamental social contract between the governed and the government. ${ }^{48}$ But when designing the structure of relationships between economic entities, primarily driven by market efficiency, it is not clear why it is the state that should guarantee a democratic process. ${ }^{49}$

But even if this restriction is accepted, jurisdictional competition remains an important alternative to centralist lawmaking in the area of contract law, the backbone of the DCFR. This does mean, however, that we have to abandon the idea that there is only one legitimate group responsible for lawmaking. Too often, only nation-states are seen as legitimate democratic lawmakers. But in an increasingly globalising and interconnected world, there is no necessary relationship between the nation-state and the legitimacy of law. The number of legal regimes need not be the same as the number of nation-states. ${ }^{\mathbf{5 0}}$ Consequently, multiple, overlapping authorities may come to coexist, with individuals primarily choosing their own authority. ${ }^{51}$

Particularly in the context of the Common Frame of Reference, we should be aware that choice is essential for its proper functioning. The DCFR provides definitions of legal terms, fundamental principles and model rules and can be used as a 'toolbox' ${ }^{\mathbf{5 2}}$ by the European legislator as a source of inspiration for the ECJ and national courts and as an optional code for contracting parties that want to make the CFR the law applicable to their contract. All these functions imply that the DCFR is only applicable if the relevant actors prefer it over national law. If the DCFR is not made applicable by the contracting parties or is

\footnotetext{
${ }^{47}$ See in more detail, also on the question of 'voice' and 'exit', J.M. SMITS, "European Private Law and Democracy", 2008, o.c., pp. 49-ff.

48 Thus HADFIELD and TALLEY, "On Public versus Private Provision of Corporate Law", Journal of Law, Economics and Organization, 2006, pp. 414-441, at p. 415.

${ }^{49} C f$ HADFIELD and TALLEY, o.c., p. 415.

${ }^{50} \mathrm{Cf}$ A. FISCHER-LESCANO and G. TEUBNER, "Regime-Collisions: The Vain Search for Legal Unity in the Fragmentation of Global Law", Michigan Journal of International Law, 2003-2004, pp. 999-1046.

${ }^{51}$ Cf S. TARROW, "Building a Composite Polity: Popular Contention in the European Union", Institute for European Studies Working Paper, No 3/98; A. HÉRITIER, o.c., p. 276.

52 European Commission, Communication on European Contract Law and the Revision of the Acquis: The Way Forward, COM (2004) 651 final, Official Journal, 2005, C 14/6, p. 14.
} 
not used as a source of inspiration by legislators or courts, the drafters are held accountable for the lack of success of this particular legal regime.

\section{B. Participation: The experience with optional instruments}

It was seen above $\mathrm{5}^{\mathbf{3}}$ that the legitimacy of rules does not necessarily have to be based on the participation of everyone in everything. The adherents of the 'democracy thesis' set out in section I seem to suggest the opposite: since all law is politics, changing the law requires a political decision by a parliament that should be involved in both the drafting and the adoption of the rules. This is a rather traditional view of democratic input and one that is clearly contradicted by our experience with the drafting of civil codes.

First, even mandatory national civil codes were often drafted without much input from parliaments. It is true that the final decision about the enactment of a code is taken by national parliaments -and when it would come to the introduction of a binding European civil code, this should also be the case-, but in drafting the code, the relevant decisions are usually made by the drafters themselves. ${ }^{54}$ This makes sense because of the often highly detailed and technical questions involved in the drafting process. Only when it comes to politically sensitive issues, such as the establishment of the proper level of consumer protection, parliaments should be involved. An important exception to this working method was the procedure followed in the establishment of the new Dutch civil code. Immediately after the start of the drafting process in 1947, a list of questions about key issues was presented to Dutch parliament. ${ }^{55}$ However, insofar as these questions involved matters of the code's structure and other typically scholarly issues, I do not see how any parliamentary input can be helpful. For instance, the question of whether a general action for unjust enrichment should be part of the code ${ }^{56}$ is not a question to be decided by parliament.

Second, it should be re-emphasised that present efforts to Europeanise private law and in particular the work on the DCFR- will not lead to rules that are binding in the same

\footnotetext{
${ }^{53}$ Section III.

54 See also P.A.J. VAN DEN BERG, The Politics of European Codification, Groningen, Europa Law Publishing, 2007.

55 See, for more details, M.W. HESSELINK, "The Ideal of Codification and the Dynamics of Europeanization: The Dutch Experience", in The Harmonisation of European Contract Law, o.c., pp. 39-ff.
} 
way as we are familiar with at the national level. If the DCFR is primarily a source of inspiration for the European legislator and the courts, or is at most an optional contract code, its legitimacy need not be found in the traditional democratic decision-process. This is confirmed by the success of various optional instruments that came into place without any input of parliaments in the drafting stage. Instead, the input consisted of a parliamentary decision to adopt an already existing instrument drafted by legal experts. The two most important examples of such instruments are the American Uniform Commercial Code (UCC) and the United Nations Convention on the International Sale of Goods (CISG). In these two cases, the only 'democratic' input consisted of individual American state parliaments -in the case of the UCC- and of national parliaments -in the case of the CISG- adopting an already existing instrument. These experiences indicate that parliaments may not necessarily be involved in the drafting of a successful code.

\section{Private law: Design or organism?}

The third building block of democracy relates to the requirement of transparency. If applied to rule-making in the field of private law, it is my view that, in particular, the quality of the deliberation is important: we have seen before that informed deliberation among specialists may lead to greater legitimacy than a general debate among non-specialists. When applied to private law, what comes closest to the transparency requirement is that new statutes and case law are assessed on the basis of the already existing coherent system, which provides us with the criteria to assess to what extent the new rules fit into the existing normative order. $^{\mathbf{5 7}}$

At the same time, however, we should be cautious in applying the requirement of transparency to the field of private law as if this is just another policy field. The reason for this relates to a more general understanding of private law. It would only be necessary to render private law completely subordinate to democratic decision-making if it is a means to a (political) end. ${ }^{\mathbf{5 8}}$ The question is whether this view of private law as a matter of conscious

\footnotetext{
56 This was a question that had in fact to be answered by Dutch parliament.

57 This can be argued for from different theoretical perspectives. See, e.g., E.J. WEINRIB, The Idea of Private Law, Cambridge, Harvard University Press, 1995; R. DWORKIN, Law's Empire, Cambridge, Harvard University Press, 1985.

${ }^{58}$ Cf B.Z. TAMANAHA, Law as a Means to an End, Cambridge, Cambridge University Press, 2006.
} 
design by some legislator is in line with the nature of the field. Most of the time, private law is seen as independent from state institutions, having a rationality of its own. ${ }^{\mathbf{5 9}}$ The private law system has developed over the ages in a long process of trial and error. ${ }^{60}$ The spontaneous development towards the standards that a community prefers provides this area of law with a rationality of its own which is independent from most public aims. ${ }^{\mathbf{6 1}}$

If we thus understand private law more as an organism than as a product of explicit design, it becomes clear why democratic input in this area of law can only have a limited impact. The Machbarkeit ["makeability"] of the law of contracts, tort and property is limited, and the view that private law is an instrument with which to change the existing distribution of power and richess ${ }^{62}$ should be regarded with suspicion. This would mean that private law serves distributive justice, a view defended before by Anthony Kronman. ${ }^{63}$ The most important objection against this position is that distributive justice requires a political decision to choose, out of all possible distributions of wealth, one that best establishes the desired collective social, economic or political goal. If private law is thus made part of establishing distributive justice, it is made subordinate to this goal; if this goal is not reached, private law fails. In my view, however, it is not the state that is to decide ex ante what a just private law requires. At best, the result can be corrected ex post. ${ }^{64}$ Moreover, the redistribution of welfare through (in particular) contract law is doomed to fail because future contracting parties are not likely to contract with 'weaker' parties if they would run the risk of avoidance of their contract. This is also the message of Charles Fried:

\footnotetext{
"Redistribution is not a burden to be borne in a random, ad hoc way by those who happen to cross paths with persons poorer than themselves. Such a conception, heart-warmingly spontaneous though it may be, would in the end undermine our ability to plan and to live our lives as we choose". 65
}

\footnotetext{
59 See, e.g., WEINRIB, The Idea of Private Law, o.c.; see, for a general framework, N. JANSEN, "The Authority of the DCFR", W. MICKLITZ and F. CAFAGGI, After the Common Frame of Reference: What Future for European Private Law?, 2009.

${ }^{60}$ This is not to deny there are differences between civil law and common law, though not as profound as suggested by, e.g., E.L. GLAESER and A. SHLEIFER, "Legal Origins", Quarterly Journal of Economics, 2001, pp. 1193-1229.

${ }^{61}$ Cf F.A. HAYEK, Law, Legislation and Liberty, London, Routledge, 1973-1979.

${ }^{62} C f$ STUDY GROUP ON SOCIAL JUSTICE IN EUROPEAN PRIVATE LAW, o.c., pp. 653-ff.

${ }^{63}$ A. KRONMAN, "Contract Law and Distributive Justice", Yale Law Journal, 1980, pp. 472-511.

${ }^{64}$ Cf WEINRIB, The Idea of Private Law, o.c., pp. 211-ff.
} 
The above does not imply that democratic input is never useful; it does imply, however, that the degree of legitimacy is dependent on the type of law being put into place. Facilitative law needs less legitimacy than mandatory law. Put otherwise: national democratic input is useful in the case of interventionist law, such as consumer protection and employment law, because preferences as to the level of intervention differ between countries. In facilitative law, preferences are better revealed by jurisdictional competition. ${ }^{\mathbf{6}}$

\section{$\underline{\text { V. Conclusions }}$}

The main argument of this article is that 'democratic' legitimacy does not have to come about through territorial entities such as national parliaments. There are other methods of legitimating law; which method is best, depends on a range of factors such as the type of rules and the level of harmonisation. In the case of the Draft CFR, it is important to realise that it is at most a source of inspiration for European and national legislators and courts and an optional code to be chosen by contracting parties if they believe it serves their interests better than national law. This optional character of the DCFR must mean something for its legitimacy. It is primarily the participation of the mentioned actors that decides on the actual legitimacy of the non-binding DCFR. This does not exclude that parliaments can still play a role -for example, by ex post accepting "public acts characterised by expertise and rationality"- ${ }^{67}$ but it is different from the role they have to play in setting mandatory rules.

The approach set out in this contribution opens the possibility to investigate whether the new types of law described in section II meet the necessary requirements of legitimacy. The mere fact that these types of law are often set at the European or global level and do not pass through national parliaments is, as such, not relevant in assessing their merits. What is relevant is to what extent they meet the requirements of participation, accountability and transparency. This differentiated approach, in which each new type of rules is assessed on the basis of these factors, was applied here to the case of the DCFR. It shows that the 'democracy thesis' cannot be accepted: new forms of private law require new forms of legitimacy.

${ }^{65}$ C. FRIED, Contract as Promise: A Theory of Contractual Obligation, Cambridge, Harvard University Press, 1981, p. 106.

${ }^{66}$ N. GAROUPA and A. OGUS, "A Strategic Interpretation of Legal Transplants", Journal of Legal Studies, 2006, pp. 339-363, at pp. 341-342.

${ }^{67}$ See DELBRÜCK, o.c., p. 40. 